УДК 556:550.845 (292.511/.516)

\title{
ПЕРВЫЕ ИЗОТОПНО-ГИДРОГЕОХИМИЧЕСКИЕ ДАННЫЕ ПО ПРИРОДНЫМ ВОДАМ ЮГО-ВОСТОЧНОГО СКЛОНА КРЯЖА ЧЕКАНОВСКОГО (АРКТИЧЕСКИЕ РАЙОНЫ СИБИРСКОЙ ПЛАТФОРМЫ)
}

\author{
Новиков Дмитрий Анатольевич1,2, \\ NovikovDA@ipgg.sbras.ru
}

\author{
Максимова Анастасия Алексеевна² \\ rock.nastaya64@gmail.com
}

Пыряев Александр Николаевич3,2,
pyrayev@igm.nsc.ru

Ян Петр Александрович1,2, YanPA@ipgg.sbras.ru

1 Институт нефтегазовой геологии и геофизики им. А.А. Трофимука СО РАН, Россия, 630090, г. Новосибирск, пр. Академика Коптюга, 3/6.

2 Новосибирский национальный исследовательский государственный университет, Россия, 630090, г. Новосибирск, ул. Пирогова, 1.

3 Институт геологии и минералогии им. В.С. Соболева СО РАН, Россия, 630090, г. Новосибирск, пр. Академика Коптюга, 3

\begin{abstract}
Актуальность исследования обусловлена получением материалов по неизученным ранее природным водам юго-восточного склона кряжа Чекановского (арктические районы Сибирской платформы). Исследуемый район относится к труднодоступным, со сплошным распространением многолетнемерзлых пород.

Цель: выявить геохимические особенности природных вод юго-восточного склона кряжа Чекановского.

Методы. Полевое опробование проведено в соответствии с общепринятыми методиками. Химико-аналитические исследования выполнены методами титриметрии, ионной хроматографрии и масс-спектрометрии с индуктивно связанной плазмой. Анализ изотопных отношений $\delta D, \delta^{18} \mathrm{O}, \delta^{13} \mathrm{C}$ проводился на приборе Isotope Ratio Mass Spectrometer Finnigan ${ }^{T M}$ MAT 253, снабженном приставками пробоподготовки H/Device (для анализа отношений $\delta D$ ) и GasBench II (для анализа отношений $\delta^{18} \mathrm{O}$ и $\left.\delta^{13} \mathrm{Colc}\right)$. При анализе гидрогеохимической инфрормации использовались коэфффициенты:: геохимические (Ca/ $\mathrm{Na}, \mathrm{Ca} / \mathrm{Mg}, \mathrm{Ca} / \mathrm{Si}$, $\mathrm{Mg} / \mathrm{Si}, \mathrm{Na} / \mathrm{Si}, \mathrm{Si} / \mathrm{Na}, \mathrm{rNa} / \mathrm{rCl}$ и SO $4 / \mathrm{Cl})$, концентрации и водной миграции по А.И. Перельману.

Результаты. Представлены первые результаты изотопно-геохимических исследований природных вод юго-восточного склона кряжа Чекановского, расположенного в низовьях реки Лены, в арктических районах Сибирской платформы. Изучены реки и временные водотоки, образующиеся в период таяния многолетнемерзлых пород. Установлено, что воды ультрапрес-

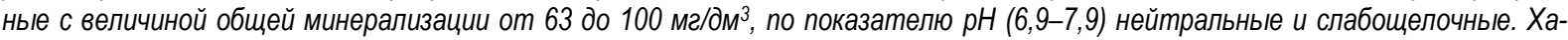
рактеризуются показателем химического потребления кислорода от 1,6 до 9,7 мгО/дм. Речные воды имеют преимущественно гидрокарбонатный кальциевый состав. Временные водотоки отличаются преобладанием сульфрат-иона, а также низкими значениями ХПК от 1,6 до 3,1 мгО/дм³. Рассчитанные коэффрициенты водной миграции распределились следующим образом: очень сильная интенсивность миграции I, Se, Br; сильная Sr, B, Sb; средняя As, P, Ni, Cu, Li, Ba, Zn, U, Sn, Mo; слабая (инертная) Sc, Y, Be, Mn, Pb, Si, Ge, Cr, Rb, Co, V, Fe, Ga, Th, Al, Zr, Ti. Изотопнье отношения кислорода и водорода изучаемых вод варьируют в широком диапазоне для $\delta^{18} \mathrm{O}$ : от -24,2 до -19,5\%, и для $\delta D-$ от -183,0 до -149,3\%. По изотопному составу воды имеют метеорное происхождение. Наблюдается смещение акцента питания вод от зимнего к летнему для рек, в то время как для временных водотоков в большей степени проявляются зимние (снеговые) источники. Изотопные отношения

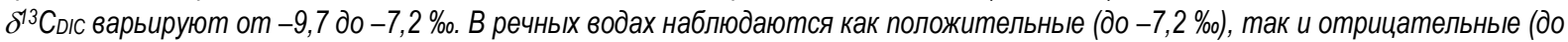
$-9,7 \%$ о отклонения $\delta^{13} C_{\text {DIC }}$ относительно проб, отобранных из временных водотоков. Для них характерны значения от $-8,0$

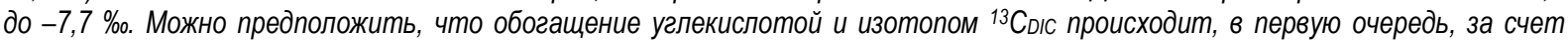
карбонатных пород и углекислоты, образованной в ходе вегетации растений типа $\mathrm{C}_{4}$.
\end{abstract}

\section{Ключевые слова:}

Природные воды, химический состав, стабильные изотопы $\delta^{18} \mathrm{O}, \delta D, \delta^{13} \mathrm{C}$, многолетнемерзлые породы, интенсивность водной миграции элементов, юго-восточный склон кряжа Чекановского, Сибирская платформа, Арктика.

\section{Введение}

Лена является одной из крупнейших рек России, которая протекает от юга Сибирской платформы и впадает в море Лаптевых, образуя крупную дельту. Река является источником хозяйственно-питьевого водоснабжения девяти административных районов Республики Саха (Якутия) и ее столицы - г. Якутска с населением более
230 тысяч человек. В научной литературе отсутствуют сведения о изотопном составе природных вод ее бассейна, что является крайне важной проблематикой при изучении крупнейших рек Сибирской Арктики, чьи водосборы подстилаются многолетнемерзлыми породами. В настоящее время антропогенная нагрузка на нее значительно возрастает, что связано с активным освоением природных 
ресурсов. Источниками загрязнения выступают промышленно-бытовые отходы населенных пунктов, нефтяных промыслов и предприятий алмазо- и золотодобывающей промышленности. Целью настоящего исследования является получение актуальных сведений о химическом и изотопном составе природных вод ее бассейна, которые будут положены в основу оценки экологического состояния и качества вод для целей хозяйственно-питьевого водоснабжения населения. Дальнейшие работы будут связаны с изучением процессов формирования их состава, что сопряжено с получением (накоплением) нового фактического материала на единой методической основе по природным водам и горным породам.

\section{Объект и методика исследований}

Административно район работ площадью около 40 км $^{2}$ располагается на территории Булунского улуса Республики Саха (Якутия) и приурочен к юговосточному склону кряжа Чекановского, вдоль левого берега р. Лена между устьями рек Буотар и Атыркан на расстоянии от 10 до 24 км вниз по течению от поселка Чекуровка (рис. 1). Бассейны рек Буотар и Атыркан расположены в условиях преимущественно денудационно-эрозионного северо-тундрового ландшафта, представленного холмистым, реже грядоувалистыми плато с нагорными террасами, курумами, мерзлотно-солифлюкционными формами. Исследуемая территория относится к Северной субаэральной криогенной области [1] Мощность многолетнемерзлых пород превышает 400 м при средней температуре ниже $-9^{\circ}$. Сезонно-талый слой варьирует от 0,5 до 1,5 м. Четвертичные отложения представлены главным образом нерасчлененными делювиальными образованиями с участием солифлюксия, коллювия и элювия. Под ними залегают меловые валанжинские глинисто-терригенные, готерив-барремские и аптские угленосные алеврито-песчаные, в меньшей степени средне-верхнеюрские алевро-песчаные отложения. В непосредственной близости к юго-западу от изученных объектов располагается Эекитский прогнозируемый золото-алмазный рассыпной узел [2].

В период с 21 июля по 1 августа 2019 г. в ходе работ полевого отряда «Чекуровский» ИНГГ СО РАН под руководством О.С. Урман на обнажениях в нижнем течении р. Лена были отобраны шесть проб природных вод. Полевое опробование из устьев рек Буотар Атыркан, Непелях и сезонных водотоков проведено в соответствии с общепринятыми методиками.

Лабораторное изучение химического состава методами титриметрии, ионной хроматографии, массспектрометрии с индуктивно-связанной плазмой (ИСП), проводилось в Проблемной научноисследовательской лаборатории гидрогеохимии Инженерной школы природных ресурсов ТПУ (аналитики О.В. Чеботарева, Н.В. Бублий, А.С. Погуца, В.В. Куровская, К.Б. Кривцова, Л.А. Ракул).

Анализ комплекса изотопных отношений $\delta \mathrm{D}, \delta^{18} \mathrm{O}$ $\delta^{13} \mathrm{C}_{\text {DIC }}$ вод и растворенного неорганического углерода (Dissolved Inorganic Carbon (DIC)) проводился в центре коллективного пользования Института геологии и минералогии им. В.С. Соболева СО РАН с по- мощью прибора Isotope Ratio Mass Spectrometer Finnigan $^{\text {TM }}$ MAT 253, снабженного приставками пробоподготовки H/Device (для анализа отношений $\delta \mathrm{D}$ ) и GasBench II (для анализа отношений $\delta^{18} \mathrm{O}$ и $\delta^{13} \mathrm{C}_{\text {DIC) }}$ ). Изотопные отношения $\delta^{13} \mathrm{C}_{\mathrm{DIC}}, \delta \mathrm{D}$ и $\delta^{18} \mathrm{O}$ измерялись относительно мировых стандартов: VSMOW2; SLAP2; GISP - для анализа изотопных отношений водорода и кислорода; NBS-18; NBS-19 - для анализа $\delta^{13} \mathrm{C}_{\text {DIC. }}$ Ошибка определения изотопного состава стандартов по углероду и кислороду - не более 0,1 \%, по водороду - не более $2 \%$.

\section{Результаты исследований и обсуждение}

\section{Особенности геохимии природных вод}

Воды изучаемого региона (рек и временных водотоков) ультрапресные с величиной общей минерализации, варьирующей от 63 до 100 мг/дм³, нейтральные и слабощелочные (рH 6,6-7,9), характеризуются показателем химического потребления кислорода (ХПК) от 1,6 до 9,7 мгО/дм ${ }^{3}$, содержанием кремния от 0,6 до 1,3 мг/дм ${ }^{3}$ и с преобладанием в составе гидрокарбонат-иона (до 58 мг/дм ${ }^{3}$ ) и кальция (до 19 мг/дм³) (табл. 1). Отличительными чертами временных водотоков являются: преобладание в их составе сульфатиона до 36 мг/дм ${ }^{3}$ в водопаде № 1 (№ 3), 27 мг/дм³ - в водопаде № 2 (№ 4) и до 24 мг/дм³ в водопаде (косой распадок) (№ 5), а также низкие значения ХПК $\left(1,6-3,1 \mathrm{мгO} /\right.$ дм $\left.^{3}\right)$, которые показывают количество кислорода, необходимое для химического окисления органических соединений. Так, воды р. Непелях (№ 2, рис. 1) имеют $\mathrm{SO}_{4}-\mathrm{HCO}_{3} \mathrm{Na}-\mathrm{Ca}$ состав с величиной общей минерализации 83 мг/дм ${ }^{3}$, нейтральным $\mathrm{pH}=7,5$ и содержанием $\mathrm{Si} 1,1$ мг/дм ${ }^{3}$. В них выявлены низкие концентрации $\mathrm{SO}_{4}{ }^{2-}$ и $\mathrm{Mg}^{2+}$, не превышающие 7,8 и 1,2 мг/дм ${ }^{3}$ соответственно, а также максимальные $-\mathrm{Cl}^{-}$до 3,4 мг/дм и $\mathrm{Na}^{+}$до 3,0 мг/дм ${ }^{3}$. Воды водопада № 1 (№ 3, рис. 1) характеризуются $\mathrm{HCO}_{3}-\mathrm{SO}_{4}$ $\mathrm{Mg}-\mathrm{Ca}$ химическим типом с величиной общей минерализации 93 мг/дм ${ }^{3}$, pH 7,3, ХПК 1,6 мгО/дм ${ }^{3}$ и содержанием Si 1,2 мг/дм³. Отмечаются максимальные содержания $\mathrm{SO}_{4}{ }^{2-}\left(35,9\right.$ мг/дм $\left.{ }^{3}\right)$ и минимальные $\mathrm{Cl}^{-}$ $\left(0,4 \mathrm{мг} /\right.$ дм $\left.^{3}\right)$ и $\mathrm{Na}^{+}\left(1,4\right.$ мг/дм $\left.{ }^{3}\right)$. В водах водопада (косой распадок) (№ 5, рис. 1) с $\mathrm{HCO}_{3}-\mathrm{SO}_{4} \mathrm{Na}-\mathrm{Mg}-\mathrm{Ca}$ составом отличаются величиной общей минерализации (63 мг/дм $\left.{ }^{3}\right)$, более низким $\mathrm{pH} 6,9$, ХПК $3,1 \mathrm{мгO} /$ дм $^{3}$ и концентрациями Si 0,6 мг/дм³. В данном водопункте выявлены минимальные концентрации гидрокарбонат-иона (19 мг/дм $\left.{ }^{3}\right)$ и $\mathrm{Ca}^{2+}\left(12 \mathrm{мг} /\right.$ дм $\left.^{3}\right)$, повышенные концентрации $\mathrm{SO}_{4}^{2-}\left(24 \mathrm{Mг} /\right.$ дм$\left.^{3}\right)$ и $\mathrm{Cl}^{-}$ $\left(2,4\right.$ мг/дм $\left.{ }^{3}\right)$. Анализ имеющихся данных выявил общие геохимические черты вод р. Буотар (№ 1), водопада № 2 (№ 4) и р. Атыркан (№ 6). Они имеют $\mathrm{SO}_{4}-\mathrm{HCO}_{3}$ $\mathrm{Mg-Ca} \mathrm{состав} \mathrm{с} \mathrm{величиной} \mathrm{общей} \mathrm{минерализации} \mathrm{от} 97$ до 100 мг/дм ${ }^{3}$, характеризуются слабощелочными $\mathrm{pH}$ $(7,6-7,9)$, ХПК 9,7 мгО/дм и содержаниями $\mathrm{Si}$ от 0,9 до 1,3 мг/дм ${ }^{3}$. Для сравнения, воды протекающей к западу от изучаемой территории р. Оленек характеризуются $\mathrm{SO}_{4}-\mathrm{HCO}_{3} \mathrm{Ca}$ составом с величиной общей минерализации от 5,6 до 11,6 мг/дм ${ }^{3}, \mathrm{pH}$ от нейтральных до сла-

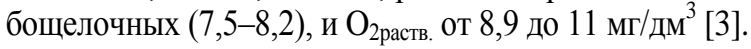



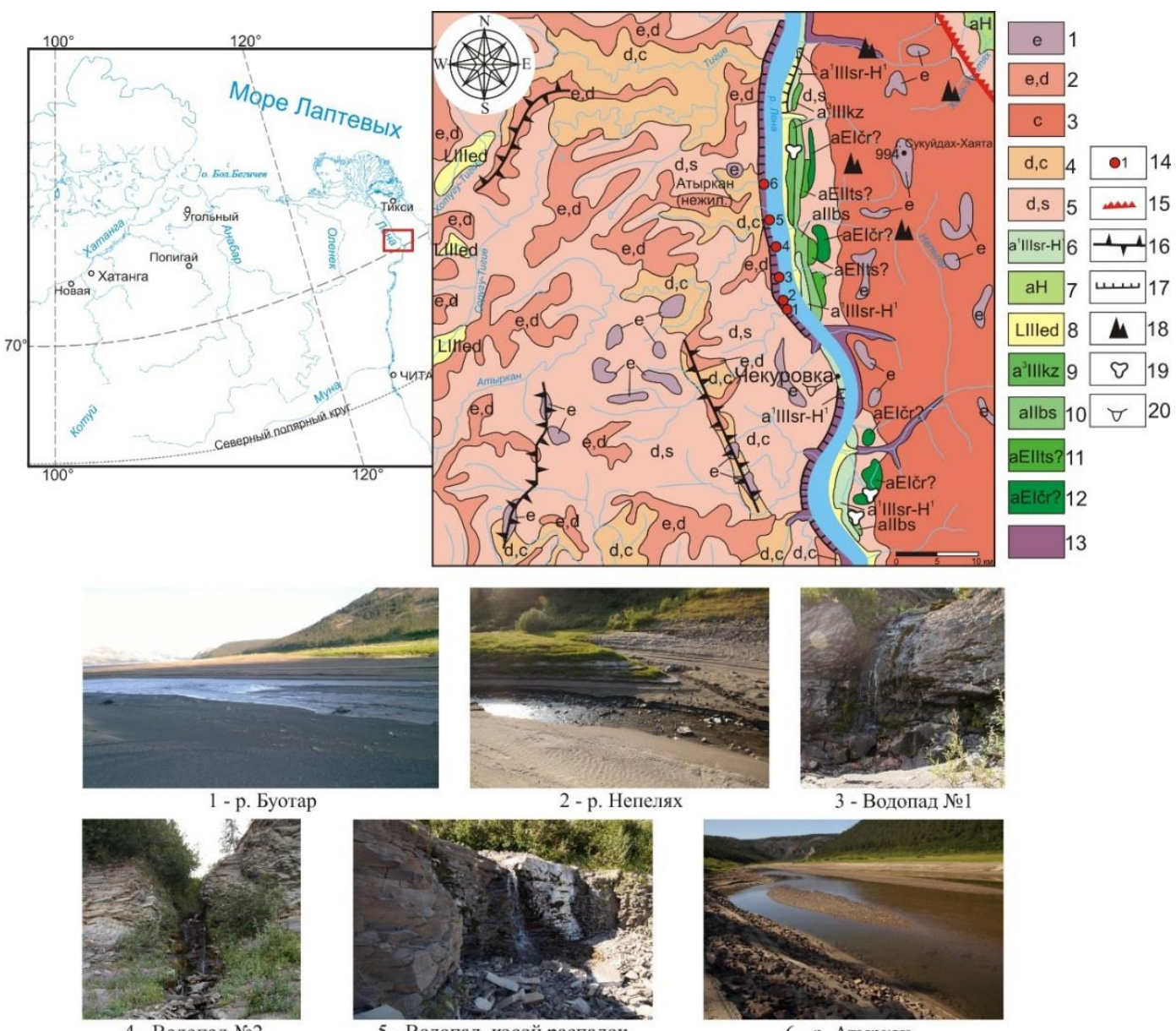

4 - Водопад №2

5 - Водопад, косой распадок

6 - р. Атыркан

Pис. 1. Местоположение района исследований. Нерасчлененные образования: 1 - элювий: дресвяники щебнистые, дресвяники гльбовые (до 3 м), 2 - элювий и делювий: супеси, суглинки со щчебнем и дресвой (1-3 м), 3 - коллювий: щебени глыбовые (до 8 м), 4 - делювий и коллювий: щеебни глыбовые, щеебни дресвяные, суглинки (до 20 м), 5 - делювий и солифлюкский: щебни с песчано-глинистым заполнением (до 20 м); 6 - сартанский горизонт голоцен, нижняя часть, аллювий первой надпойменной террасы: галечники, пески, супеси, суглинки, линзы торфа, клинья льда (до 16 м); 7 - алювий русла, поймы и первой надпойменной террасы: пески, галечники, алевролиты, суглинки, супеси, глины, торф (до 15 м) (вмещают малые россыпные месторождения и шлиховые ореоль золота); 8 - едомная свита, лессовидные криогенные полигенетические образования: супеси, суглинки, алевролиты, пески, линзы торфа, ископаемые льды (более 35 м); 9 - казанцевский горизонт, аллювий третьей надпойменной террасы: галечники, супеси, пески, гравийники (до 8 м); 10 - бестяхская свита, аллювий одноименной террасы: галечники, гравийники, пески (до 14 м) (вмещают шлиховые ореолы золота); 11 - тустахская свита, аллювий одноименной террасы: галечник, гравийники (до 2,5 м) (вмещают шлиховые ореоль золота); 12 - черендейская свита, аллювий одноименной террасы: галечники глинистые и песчаные, супеси (до 4 м); 13 - дочетвертичные образования, не разделенные по типу пород; 14 - объекты изучения; 15 - тектонические уступы по разрывным нарушениям, активным в четвертичное время; 16 - гряды; 17 эрозионные уступы; 18 - структурно-денудационные останиы, не выражающиеся в масштабе карты; места находок ископаемых остатков: 19 - спор и пыльцы; 20 - позвоночных

Fig. 1. Location of the study area. Poorly defined formations: 1 - eluvium: arenas schistose, arenas block (less than $3 \mathrm{~m}$ ), 2 - eluvium and deluvium: sands loam, mild clays with break stone and landwaste $(1-3 \mathrm{~m}), 3$ - colluvium: break stone block (less than $8 \mathrm{~m}$ ), 4 - deluvium and colluvium: break stone block, break stone rotten stone, mild clay (less than $20 \mathrm{~m}$ ), 5 -deluvium and solifluksium: break stone with sand-clay filling (less than $20 \mathrm{~m}$ ); 6 - sartanskiy horizon-Holocene, low part: alluvium first underfloodplain terrace: bench gravel, sands, sand loam, mild clay, peat lenses, ice wedges (less than $16 \mathrm{~m}$ ); 7 - alluvium of channel, floodplain and the first underfloodplain terrace: sands, bench gravel, aleurolite, mild clay, sand loam, clays, peat (less than $15 \mathrm{~m}$ ) (accommodate small alluvial deposits and schlichow gold halos); 8 - yedomnaya formation, loessoid cryogenic polygenetic formations: mild clay, sand loam, aleurolite, sands, peat lenses, fossil ice (above $35 \mathrm{~m})$; 9 - kazantsevsky horizon, alluvium of the third underfloodplain terrace: pebbles, sandy loam, sand, gravel (less than $8 \mathrm{~m}$ ); 10 - bestyakhskaya formation, alluvium of the same name terrace: pebbles, gravels, sands (less than $14 \mathrm{~m}$ ) (accommodate concentrate halos of gold); 11 - tustakhskaya formation, alluvium of the same name terrace: pebble, gravel (less than 2,5 m) (accommodate concentrate halos of gold); 12 - cherendeyskaya formation, alluvium of the same name terrace: clay pebbles and sand loam (less than $4 \mathrm{~m}$ ); 13 - pre-Quaternary formation, of unseparated type of rocks; 14 - objects of study; 15 - tectonic ledges separated by breaking fault, active in the Quaternary; 16 - ridge; 17 - erosion ledges; 18 - structural-denudation relics, not expressed in the map scale; places of fossil finds: 19 - spore and pollen; 20 -vertebrates 
Рассчитанные геохимические коэффициенты показали, что воды временных водотоков № 1 и 2 отличаются высоким отношением $\mathrm{SO}_{4} / \mathrm{Cl}$ (46-83). Предположительно это связано с дренированием массива пород с наличием сульфидной минерализации. О преобладании во вмещающих породах кальциевых минералов говорит отношение $\mathrm{Ca} / \mathrm{Si}$, которое возрастает от 14 до 20 по гидрогеохимическому профилю от водопункта № 1 к № 6. По другим геохимическим коэффициентам $(\mathrm{Ca} / \mathrm{Na}, \mathrm{Ca} / \mathrm{Mg}, \mathrm{Mg} / \mathrm{Si}, \mathrm{Na} / \mathrm{Si}, \mathrm{Si} / \mathrm{Na}$, $\mathrm{rNa} / \mathrm{rCl})$ не удалось выявить значимых различий (табл. 2).

Спектр распределения элементов изученных вод (рис. 2, a) выявил наибольшие содержания у $\mathrm{Si}$ $\left(1,27\right.$ мг/дм $\left.{ }^{3}\right), \mathrm{Al}\left(0,04\right.$ мг/дм $\left.{ }^{3}\right), \mathrm{Fe}\left(0,06\right.$ мг/дм $\left.{ }^{3}\right)$ и $\mathrm{Sr}$ $\left(1,15 \mathrm{мг} /\right.$ дм $\left.^{3}\right)$. С ростом общей минерализации увеличиваются концентрации $\mathrm{B}, \mathrm{Si}, \mathrm{Sc}, \mathrm{V}, \mathrm{Cr}, \mathrm{Mn}, \mathrm{Co}, \mathrm{Cu}$,
$\mathrm{Zn}, \mathrm{Ga}, \mathrm{As}, \mathrm{Se}, \mathrm{Br}, \mathrm{Rb}, \mathrm{Y}, \mathrm{Sn}, \mathrm{Ba}, \mathrm{Pb}, \mathrm{Th}, \mathrm{U}$ и снижаются содержания $\mathrm{Ti}, \mathrm{Al}, \mathrm{Fe}, \mathrm{Ni}, \mathrm{Ge}, \mathrm{Sr}, \mathrm{Sb}, \mathrm{I}$. Среди изученных водопунктов воды реки Непелях (№ 2) характеризуются минимальными содержания $\mathrm{Pb}$ до $9 \cdot 10^{-6}$ и Th до $2 \cdot 10^{-6}$ мг/дм³ ${ }^{3}$ В водопаде № 1 (№ 3) выявлены повышенные содержания Zn $\left(0,001 \mathrm{мг} /\right.$ дм $\left.^{3}\right)$, а во временном водотоке № 2 (№ 4) установлены минимальные содержания $\mathrm{Mn}\left(0,0003\right.$ мг/дм $\left.{ }^{3}\right), \quad \mathrm{Ti}$ $\left(0,0002\right.$ мг/дм $\left.{ }^{3}\right), \mathrm{V}\left(9 \cdot 10^{-6}\right.$ мг/дм $\left.{ }^{3}\right)$ и максимальные концентрации $\operatorname{Br}\left(0,013\right.$ мг/дм $\left.{ }^{3}\right)$, Мо $\left(0,0003\right.$ мг/дм $\left.{ }^{3}\right)$ и $\mathrm{Zn}\left(0,002\right.$ мг/дм $\left.{ }^{3}\right)$. В водопаде (косой распадок) (№ 5) выявлены максимально высокие на изучаемой территории содержания $\mathrm{Ni}\left(0,003\right.$ мг/дм $\left.{ }^{3}\right)$ и I $\left(0,071 \mathrm{мг} /\right.$ дм $\left.^{3}\right)$. Воды реки Атыркан (№ 6) характеризуются пониженными концентрациями Th $\left(3 \cdot 10^{-6}\right.$ мг/дм $\left.{ }^{3}\right)$, а также максимальными содержаниями $\mathrm{Zn}\left(0,003\right.$ мг/дм $\left.{ }^{3}\right)$ и $\operatorname{Mn}\left(0,01\right.$ мг/дм $\left.{ }^{3}\right)$.
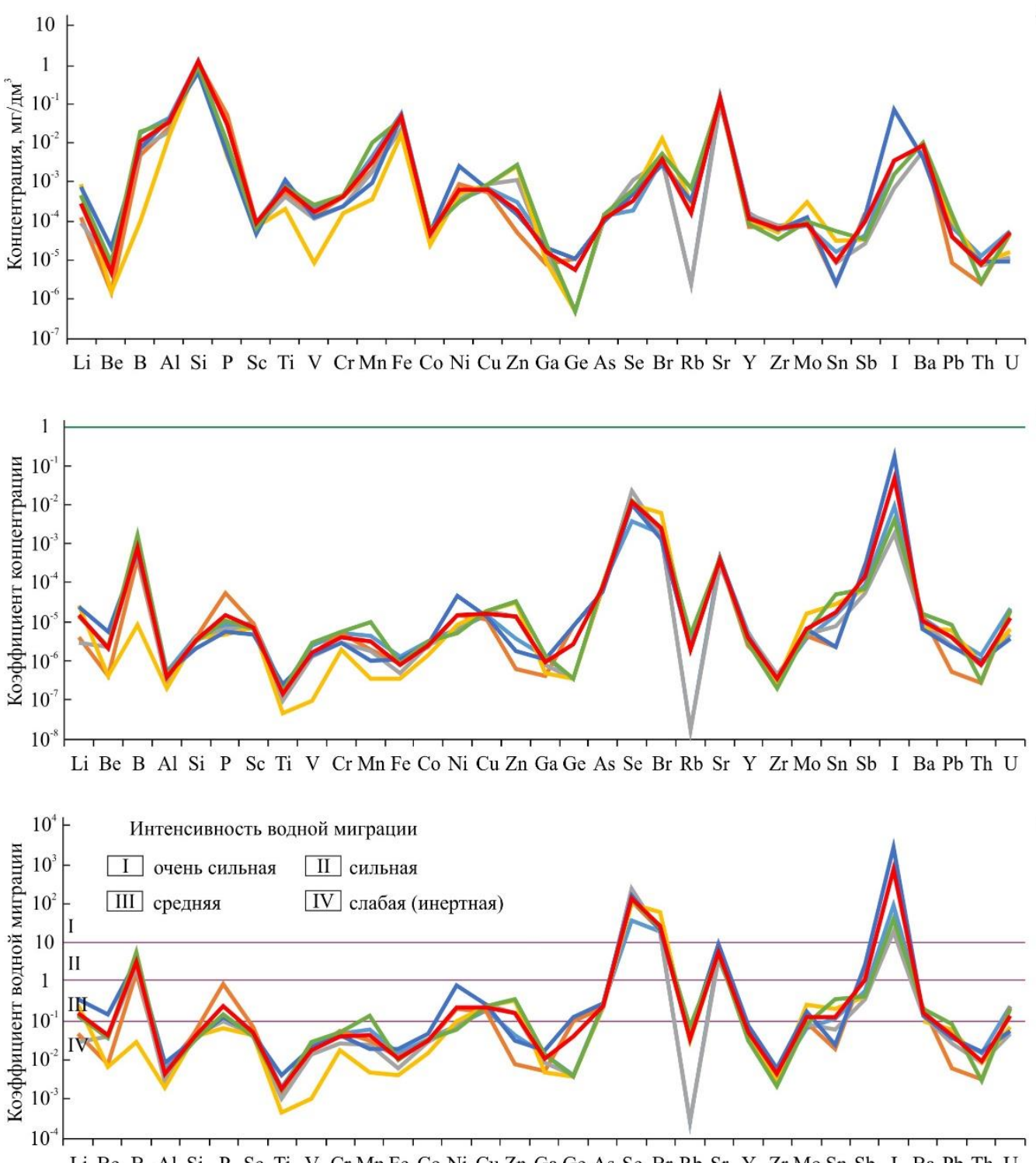

Li Be B Al Si P Sc Ti V Cr Mn Fe Co Ni CuZn Ga Ge As Se Br Rb Sr Y Zr Mo Sn Sb I Ba Pb Th U

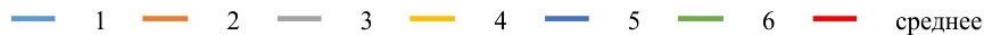

Puс. 2. Спектр распределения микрокомпонентов в природных водах юго-восточного склона кряжа Чекановского (а), распределение коэффициентов концентраций (б), ряды миграции микрокомпонентов в природных водах (в)

Fig. 2. Spectrum of trace elements distribution in natural waters of south-east slope of the Chekanovsky ridge (a), distribution of concentration factors $(b)$, microelements migration series in natural waters $(c)$ 
Для оценки степени накопления в водах химических элементов были рассчитаны коэффициенты концентрации, которые отражают отношение содержаний элементов в воде к вмещающим породам или к кларку литосферы. Их анализ выявил следующий ряд (рис. 2, б):

$\mathrm{I}\left(5 \cdot 10^{-2}\right)>\operatorname{Se}\left(1 \cdot 10^{-2}\right)>\operatorname{Br}\left(2 \cdot 10^{-3}\right)>\mathrm{B}\left(8 \cdot 10^{-4}\right)>\operatorname{Sr}\left(4 \cdot 10^{-4}\right)>$ $\mathrm{Sb}\left(1 \cdot 10^{-4}\right)>\operatorname{As}\left(7 \cdot 10^{-5}\right)>\operatorname{Sn}\left(2 \cdot 10^{-5}\right)>\mathrm{Cu}\left(2 \cdot 10^{-5}\right)>\mathrm{P}\left(1 \cdot 10^{-5}\right)>$ $\mathrm{Ni}\left(1 \cdot 10^{-5}\right)>\mathrm{Li}\left(1 \cdot 10^{-5}\right)>\mathrm{Zn}\left(1 \cdot 10^{-5}\right)>\mathrm{U}\left(1 \cdot 10^{-5}\right)>\mathrm{Ba}\left(1 \cdot 10^{-5}\right)>$ $\mathrm{Sc}\left(7 \cdot 10^{-6}\right)>\mathrm{Mo}\left(7 \cdot 10^{-6}\right)>\mathrm{Pb}\left(4 \cdot 10^{-6}\right)>\mathrm{Y}\left(4 \cdot 10^{-6}\right)>\mathrm{Cr}\left(4 \cdot 10^{-6}\right)>$ $\mathrm{Si}\left(3 \cdot 10^{-6}\right)>\operatorname{Mn}\left(3 \cdot 10^{-6}\right)>\operatorname{Ge}\left(3 \cdot 10^{-6}\right)>\operatorname{Co}\left(2 \cdot 10^{-6}\right)>\operatorname{Be}\left(2 \cdot 10^{-6}\right)>$ $\mathrm{Rb}\left(2 \cdot 10^{-6}\right)>\mathrm{V}\left(2 \cdot 10^{-6}\right)>\mathrm{Ga}\left(9 \cdot 10^{-7}\right)>\mathrm{Fe}\left(8 \cdot 10^{-7}\right)>\mathrm{Th}\left(8 \cdot 10^{-7}\right)>$ $\operatorname{Al}\left(4 \cdot 10^{-7}\right)>\operatorname{Zr}\left(3 \cdot 10^{-7}\right)>\operatorname{Ti}\left(1 \cdot 10^{-7}\right)$.

Чтобы оценить интенсивность водной миграции, которая определяется свойствами элемента, а также показывает степень его концентрирования или рассеяния в природных водах, были рассчитаны коэффициенты по А.И. Перельману [4]: $\mathrm{Kx}_{1}=\frac{\mathrm{m}_{\mathrm{x}} \cdot 100}{\mathrm{a} \cdot \mathrm{n}_{\mathrm{x}}}$, где $\mathrm{m}_{\mathrm{x}}$ - содержание элемента в воде (мг/дм³), a - минерализация $\left(м г /\right.$ дм $\left.^{3}\right)$ и $\mathrm{n}_{\mathrm{x}}-$ кларк литосферы в \% или содержание того же элемента во вмещающей породе. При расчетах были использованы кларки литосферы [5]. По интенсивности водной миграции химические элементы выстроились в следующую последовательность (рис. 2, в):

очень сильная $\mathrm{I}_{741}>\mathrm{Se}_{132}>\mathrm{Br}_{27}>$ сильная $>\mathrm{Sr}_{6}>\mathrm{B}_{3}>\mathrm{Sb}_{1,14}>$ средняя $>\mathrm{As}_{0,25}>\mathrm{P}_{0,24}>\mathrm{Ni}_{0,23}>\mathrm{Cu}_{0,22}>\mathrm{Li}_{0,16}>\mathrm{Ba}_{0,16}>\mathrm{Zn}_{0,16}>$

$\mathrm{U}_{0,14}>\mathrm{Sn}_{0,13}>\mathrm{Mo}_{0,12}>$ слабая(инертная) $>\mathrm{Sc}_{0,050}>\mathrm{Y}_{0,050}>$

$\mathrm{Be}_{0,045}>\mathrm{Mn}_{0,045}>\mathrm{Pb}_{0,043}>\mathrm{Si}_{0,041}>\mathrm{Ge}_{0,040}>\mathrm{Cr}_{0,040}>\mathrm{Rb}_{0,032}>$ $\mathrm{Co}_{0,031}>\mathrm{V}_{0,018}>\mathrm{Fe}_{0,011}>\mathrm{Ga}_{0,011}>\mathrm{Th}_{0,0090}>\mathrm{Al}_{0,0046}>\mathrm{Zr}_{0,0043}>\mathrm{Ti}_{0,0018}$.

Некоторые элементы из установленных А.И. Перельманом рядов миграции переходят из своих привычных групп в другие, например, Se из легкоподвижной группы переходит в высокоподвижную, а $\mathrm{Mn}$ и Со из подвижной группы переходит в инертную. В случае с селеном такой переход связан с большим антропогенным влиянием на поверхностные воды.

\section{Изотопный состав природных вод}

Стабильные изотопы водорода, кислорода и углерода природных вод позволяют изучать их историю прямыми методами. Применение комплекса изотопных отношений $\left[\delta^{13} \mathrm{C}+\delta^{18} \mathrm{O}+\delta \mathrm{D}\right]$ достоверно выявляет генезис вод [6], степень их испарения [7] и связь между водоносными горизонтами в пределах площади водосбора $[8,9]$, взаимодействие вод с дневной поверхностью [10] и вмещающими горными породами $[11,12]$, а также роль антропогенных факторов в их загрязнении [13].

Связь отношений $\delta^{18} \mathrm{O}$ и $\delta \mathrm{D}$ активно используется при построениях локальных линий метеорных вод (Local Meteoric Water Line - LMWL) [9, 10, 12, 13], отражающих соотношение между $\delta^{18} \mathrm{O}$ и $\delta \mathrm{D}$ в указанном регионе. Аналогичная линия, охватывающая глобальное среднегодовое отношение между $\delta \mathrm{D}$ и $\delta^{18} \mathrm{O}$ для природных метеорных вод (Global Meteoric Water Line - GMWL), была предложена Г. Крейгом [14] и описывается уравнением $\delta \mathrm{D}=8,0 \cdot \delta^{18} \mathrm{O}+10$. Локальные линии в большинстве случаев соотносят с GMWL. Это позволяет делать выводы об условиях осадконакопления в изучаемом регионе, эффектах темпера- турного режима и сезонности осадков, степени испарения вод, оказывающих существенное влияние как на соотношения между парой $\delta^{18} \mathrm{O}$ и $\delta \mathrm{D}$, так и на сами отношения стабильных изотопов.

На рис. 3, а и в табл. 2 представлены данные по соотношениям стабильных изотопов $\delta^{18} \mathrm{O}$ и $\delta \mathrm{D}$ природных вод, отобранных в реках и временных потоках (рис. 1). Изотопные отношения кислорода и водорода вод находятся в широком диапазоне: от $-24,2$ до $-19,5 \%$ для $\delta^{18} \mathrm{O}$ и от $-183,0$ до $-149,3 \%$ для $\delta \mathrm{D}$. Из рис. $3, a$ видно, что изотопные отношения водорода и кислорода для всех изученных вод хорошо коррелируют с GMWL (точки расположены близко к GMWL), что позволяет отнести их к метеорным. Воды исследованной области можно разделить на две группы: первая - воды, для которых $\delta^{18} \mathrm{O}$ и $\delta \mathrm{D}$ точно повторяют глобальную линию метеорных вод, и вторая воды, для которых $\delta^{18} \mathrm{O}$ и $\delta \mathrm{D}$ отклоняются от GMWL (хоть и не значительно) в сторону более тяжелого изотопного состава кислорода. Интересно отметить, что положительный сдвиг изотопного состава кислорода (от 0,5 до 0,7 \%о) характерен для рек, в то время как во временных водотоках отмечается близость изотопных отношений $\delta^{18} \mathrm{O}$ и $\delta \mathrm{D}$ к GMWL.

Обеднение изотопного состава вод легким изотопом кислорода, как правило, объясняется эффектом испарения вод [8, 9, 15, 16]. Считается [17], что наиболее сильно он проявляется в верхних слоях поверхностных вод (глубины до 1 м), где обеднение легким изотопом кислорода может достигать 4 \%. Учитывая более длинный «маршрут» следования речных вод и большую удельную поверхность контакта с атмосферой, эффект испарения в них проявлен в большей мере. В сравнении с водами временных водотоков для рек характерны более тяжелые изотопные соотношения как водорода, так и кислорода. Это указывает на различие питания этих объектов. Обогащение легким изотопом характерно для осадков холодного времени года [10]. В этой связи питание временных водотоков осуществляется в зимний период года, а рек дополняется осадками теплого сезона.

Не меньший интерес исследователей привлекает изотопный состав растворенного в водах неорганического углерода $\left(\delta^{13} \mathrm{C}_{\mathrm{DIC}}\right)[18-21]$. Значения отношений $\delta^{13} \mathrm{C}_{\mathrm{DIC}}$ позволяют оценить «наследственность» вод, определить уровень взаимодействия вод с окружением, типы окружения. Поскольку потенциальным источником гидрокарбонат-иона в природных водах может служить достаточно обширный спектр соединений, при интерпретации результатов исследования изотопных отношений углерода в углекислоте вод следует учитывать множество факторов. Самыми распространенными «донорами» растворенной в воде углекислоты считается атмосферный диоксид углерода [19], биогенная (органическая) углекислота, которая образуется в ходе жизнедеятельности растений и микроорганизмов [20], карбонатные осадочные породы, почвенный $\mathrm{CO}_{2}$, а также гидрокарбонат-ион, образуемый при гидролизе алюмосиликатов. В областях, подверженных антропогенному влиянию, следует также учитывать и техногенные источники [18]. 
$\mathrm{a} / \mathrm{a}$

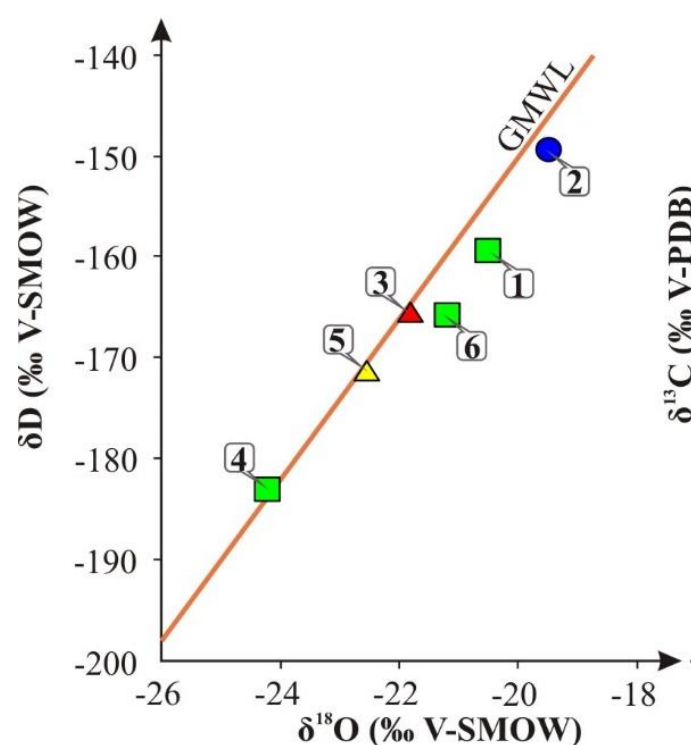

$\sigma / b$

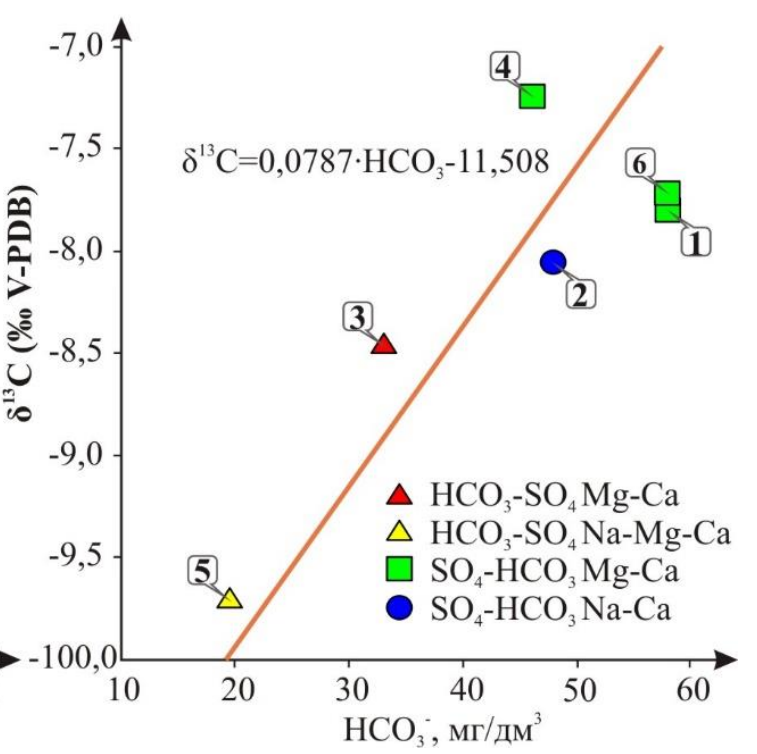

Pис. 3. Изотопные отношения $\delta D$ и $\delta^{18} O$ природных вод юго-восточного склона кряжа Чекановского (a): $p$. Буотар (1), p. Непелях (2), р. Атыркан (6); водопад № 1 (3), водопад № 2 (4); водопад (косой распадок) (5). Зависимость изотопного отношения $\delta^{13} C_{D I C}$ вод от концентрации гидрокарбонат-иона (б)

Fig. 3. Isotope ratios $\delta D$ and $\delta^{18} O$ of natural waters of south-east slope of the Chekanovsky ridge (a): $r$. Buotar (1), $r$. Nepelyakh (2), r. Atyrkan (6); waterfall no. 1 (3), waterfall no. 2 (4); waterfall (oblique decay) (5). Dependence of water isotopic ratio $\delta^{13} C_{D I C}$ on $\mathrm{HCO}_{3}$ concentration (b)

Воды исследованной области имеют узкое распределение изотопных отношений растворенной углекислоты. Изотопные отношения $\delta^{13} \mathrm{C}_{\mathrm{DIC}}$ варьируют от $-9,7$ до 7,2 \%. Для временных водотоков (№ 1, 2 и 6) значения изотопных отношений очень близки $(-7,8,-8,0$ и $-7,7 \%$, соответственно). В речных водах наблюдается как положительное (до -7,2 \%о), так и отрицательное (до -9,7 \%о) отклонение значений $\delta^{13} \mathrm{C}_{\mathrm{DIC}}$ относительно образцов, отобранных из водопадов. По данным лаборатории глобального мониторинга [22] для ближайшей станции наблюдений (гидрометеорологическая обсерватория Тикси $71.60^{\circ} \mathrm{N}$; $\left.128.89^{\circ} \mathrm{E} ; 19 \mathrm{mals}\right)$ значения $\delta^{13} \mathrm{C}$ атмосферного $\mathrm{CO}_{2}$ в указанных широтах за 2011-2019 гг. в зависимости от времени года колеблется от $-9,2$ до $-7,7$ \%о (рис. 4), со среднегодовыми значениями - около $-8,6 \%$. Переход атмосферного углекислого газа в гидрокарбонат-ион сопровождается эффектом фракционирования, при котором происходит обеднение углекислоты тяжелым изотопом ${ }^{13} \mathrm{C}$ на 1,2 \% [21]. Поэтому гипотетическое колебание изотопных отношений $\delta^{13} \mathrm{C}_{\text {DIC }}$ метеорной воды должно составлять от $-10,4$ до $-8,9 \%$ при среднегодовом $-9,8 \%$.

Из табл. 2 видно, что указанным рамкам атмосферного $\mathrm{CO}_{2}$ соответствуют только воды объекта № 5. Что характерно, именно для этого образца содержание гидрокарбонат-иона самое низкое $\left(19,5\right.$ мг/дм $\left.{ }^{3}\right)$ и наиболее близко к естественным концентрациям DIC дождевых вод неурбанизированных зон, находящимся в пределах 16,4-79,6 $\mu$ моль/л [23]. Для других объектов характерны более высокие концентрации гидрокарбонатиона. Концентрация диоксида углерода в воздухе и, соответственно, в водах сильно зависит от активности вегетации [24]. Учитывая, что отбор проб проводился в течение очень малого промежутка времени (c 21.07.2019 г. по 01.08.2019 г.), фактор изменения вегетационной активности можно не рассматривать. С ростом концентрации углекислоты в водах наблюдается увеличение «тяжелого» изотопного сдвига отношения $\delta^{13} \mathrm{C}_{\mathrm{DIC}}$ (рис. 3,6 ), достигающего максимального значения для водопунктов 1, 6 и 4. Очевидно, для этих образцов наблюдается наибольшая степень изотопного обмена углерода углекислоты с окружением. Считается [19], что на изотопный состав $\delta^{13} \mathrm{C}_{\mathrm{DIC}}$ вод активное влияние может оказывать вегетация растений. При этом важно учитывать тип фотосинтеза растений $\left(\mathrm{C}_{3}\right.$ и $\mathrm{C}_{4}$ ), поскольку он оказывает решающую роль. Наиболее наглядно влияние типа фотосинтеза растений может быть проиллюстрировано на примере выветривания континентальных карбонатов (для которых типичны $\delta^{13} \mathrm{C}$ близкие к нулю) с участием $\mathrm{CO}_{2}$, производимым растениями. При превалировании растений типа $\mathrm{C}_{3}$ конечный изотопный состав DIC, получаемый в результате смешивания углекислоты источников, равен $-9,6 \%$. В случае преобладания растений типа $\mathrm{C}_{4}$ ожидаемые значения $\delta^{13} \mathrm{C}_{\text {DIC }}$ могут достигать $-2,6 \%$ [19]. В нашем случае наиболее вероятной причиной «утяжеления» изотопного отношения $\delta^{13} \mathrm{C}_{\mathrm{DIC}}$ вод объекта № 4 представляется выветривание силикатов, содержащих углекислоту, образованную в ходе вегетации растений типа $\mathrm{C}_{4}$, которая может приводить к обогащению изотопного состава углерода вплоть до $-5,1$ \%о [19]. Нельзя также полностью исключить вероятный контакт вод источника 4 с карбонатными породами, сформированными в большинстве случаев из морских систем, богатых тяжелыми изотопами углерода и имеющими значения отношений $\delta^{13} \mathrm{C}$ близкие к нулю [25]. Тем не менее вопрос обмена вод с карбонатными породами остается открытым и требует дополнительного исследования. 


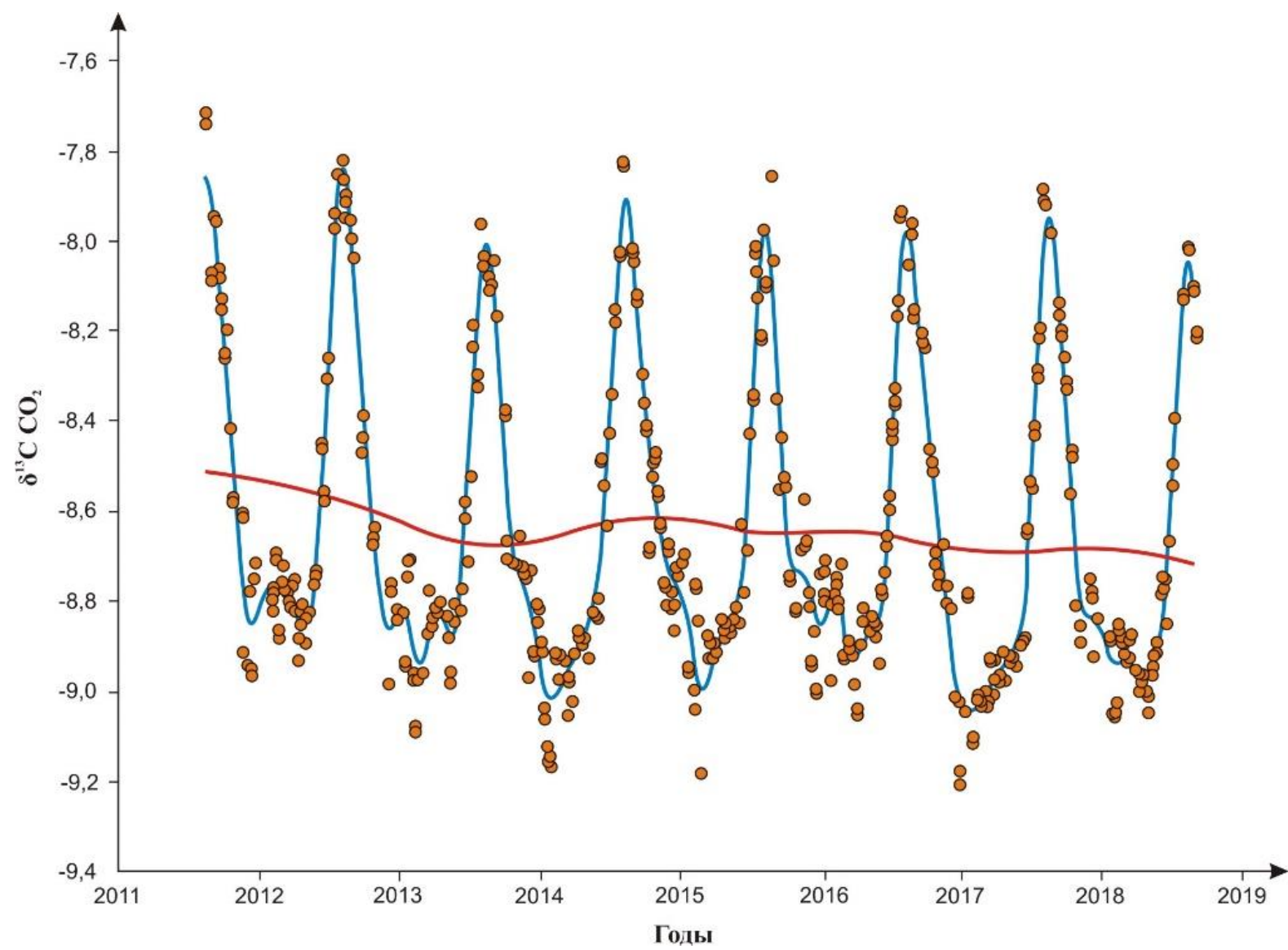

Рис. 4. Сезонные колебания изотопного отношения $\delta^{13} \mathrm{C}$ атмосферного $\mathrm{CO}_{2}$ по данным Гидрометеорологической обсерватории Тикси, Россия

Fig. 4. Seasonal fluctuations of the isotope ratio $\delta^{3} \mathrm{C}$ of atmospheric $\mathrm{CO}_{2}$ according to the Hydrometeorological Observatory Tiksi, Russia

В случае речных вод (№ 1, 6) к вышеперечисленным причинам обогащения углекислоты изотопом ${ }^{13} \mathrm{C}$ можно добавить фактор испарения и дегазации [26], приводящий к обеднению углекислоты легким изотопом и, следовательно, утяжелению изотопного отношения $\delta^{13} \mathrm{C}_{\mathrm{DIC}}$. Принимая во внимание наибольшие концентрации гидрокарбонат-иона в водопунктах 1 и 6 , следует отметить, что их обогащение углекислотой и изотопом ${ }^{13} \mathrm{C}$ происходит за счет внешних источников тяжелого изотопного состава, таких как вмещающие породы и углекислота, образованная в ходе вегетации растений типа $\mathrm{C}_{4}$.

Таблица 1. Химический состав природных вод юго-восточного склона кряжа Чекановского, мг/дм

Table 1. Chemical composition of natural waters of south-east slope of the Chekanovsky ridge, mg/l

\begin{tabular}{|c|c|c|c|c|c|c|c|c|c|c|c|}
\hline $\begin{array}{l}\text { № на pис. } 1 \\
\text { №. on Fig. } 1\end{array}$ & $\mathrm{pH}$ & $\mathrm{M}$ & $\mathrm{HCO}_{3}^{-}$ & $\mathrm{SO}_{4}^{2-}$ & $\mathrm{Cl}^{-}$ & $\mathrm{Ca}^{2+}$ & $\mathrm{Mg}^{2+}$ & $\mathrm{Na}^{+}$ & $\mathrm{K}^{+}$ & ХПК & Химический тип/Chemical type \\
\hline 1 & 7,9 & 96 & 58 & 14 & 0,6 & 18 & 2,7 & 2,4 & 0,4 & 8,9 & $\mathrm{M} 0,10 \frac{\mathrm{HCO}_{3}^{-} 75 \mathrm{SO}_{4}^{2-} 24 \mathrm{Cl}^{-} 1}{\mathrm{Ca}^{2+} 73 \mathrm{Mg}^{2+} 20 \mathrm{Na}^{+} 8 \mathrm{~K}^{+} 0,8} \mathrm{pH} 7,9$ \\
\hline 2 & 7,5 & 83 & 48 & 8 & 3,4 & 19 & 1,2 & 3 & 0,3 & & $\mathrm{M} 0,08 \frac{\mathrm{HCO}_{3}^{-} 75 \mathrm{SO}_{4}^{2-} 15 \mathrm{Cl}^{-} 9}{\mathrm{Ca}^{2+} 80 \mathrm{Na}^{+} 11 \mathrm{Mg}^{2+} 8 \mathrm{~K}^{+} 0,5} \mathrm{pH} 7,5$ \\
\hline 3 & 7,3 & 93 & 33 & 36 & 0,4 & 19 & 3,2 & 1,4 & 0,4 & 1,6 & $\mathrm{M} 0,09 \frac{\mathrm{SO}_{4}^{2-} 57 \mathrm{HCO}_{3}^{-} 41 \mathrm{Cl}^{-} 0.9}{\mathrm{Ca}^{2+} 74 \mathrm{Mg}^{2+} 20 \mathrm{Na}^{+} 5 \mathrm{~K}^{+} 0,8} \mathrm{pH} 7,3$ \\
\hline 4 & 7,6 & 98 & 46 & 27 & 0,6 & 18 & 3,9 & 2,1 & 0,4 & 3,1 & $\mathrm{M} 0,10 \frac{\mathrm{HCO}_{3}^{-} 56 \mathrm{SO}_{4}^{2-} 42 \mathrm{Cl}^{-} 1}{\mathrm{Ca}^{2+} 68 \mathrm{Mg}^{2+} 24 \mathrm{Na}^{+} 7 \mathrm{~K}^{+} 0,8} \mathrm{pH} 7,6$ \\
\hline 5 & 6,9 & 63 & 19 & 24 & 2,4 & 12 & 2,4 & 2,4 & 0,3 & & $\mathrm{M} 0,06 \frac{\mathrm{SO}_{4}^{2-} 56 \mathrm{HCO}_{3}^{-} 36 \mathrm{Cl}^{-} 8}{\mathrm{Ca}^{2+} 66 \mathrm{Mg}^{2+} 21 \mathrm{Na}^{+} 11 \mathrm{~K}^{+} 0,7} \mathrm{pH} 6,9$ \\
\hline 6 & 7,7 & 100 & 58 & 16 & 0,8 & 18,8 & 3,1 & 2,6 & 0,6 & 9,7 & $\mathrm{M} 0,10 \frac{\mathrm{HCO}_{3}^{-} 72 \mathrm{SO}_{4}^{2-} 26 \mathrm{Cl}^{-} 2}{\mathrm{Ca}^{2+} 71 \mathrm{Mg}^{2+} 19 \mathrm{Na}^{+} 8 \mathrm{~K}^{+} 1,1} \mathrm{pH} 7,7$ \\
\hline
\end{tabular}


Таблица 2. Геохимические и изотопные особенности природных вод юго-восточного склона кряжа Чекановского

Table 2. Geochemical and isotopes features of natural waters of south-east slope of the Chekanovsky ridge

\begin{tabular}{|c|c|c|c|c|c|c|c|c|c|c|c|c|c|c|}
\hline $\begin{array}{l}\text { № на рис. } 1 \\
\text { №. on Fig. } 1\end{array}$ & $\sum_{\tilde{J}}^{\widetilde{J}}$ & $\sum_{J}^{\infty}$ & $\overline{\tilde{w}}$ & $\frac{\vec{w}}{\sum^{50}}$ & $\begin{array}{l}\overline{\mathbf{n}} \\
\bar{z}\end{array}$ & $\sum_{i=n}^{\pi}$ & $\begin{array}{l}\bar{\nu} \\
\stackrel{\widetilde{T}}{Z}\end{array}$ & 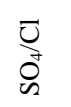 & $\stackrel{\circ}{\circ}$ & @i & $\begin{array}{l}\infty \\
\infty \\
\infty \\
\infty\end{array}$ & $\begin{array}{l}0 \\
\frac{\infty}{4} \\
\frac{\infty}{4}\end{array}$ & 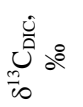 & 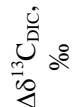 \\
\hline 1 & 7,5 & 6,7 & 14,2 & 2,1 & 1,9 & 0,5 & 6,0 & 23,8 & $-159,2$ & 1,4 & $-20,5$ & \multirow{6}{*}{0,1} & $-7,8$ & \multirow{6}{*}{0,1} \\
\hline 2 & 6,3 & 15,6 & 16,5 & 1,1 & 2,6 & 0,4 & 1,4 & 2,3 & $-149,3$ & $-0,4$ & $\begin{array}{l}-19,5 \\
\end{array}$ & & $-8,0$ & \\
\hline 3 & 13,5 & 6,0 & 16,1 & 2,7 & 1,2 & 0,8 & 5,1 & 83,5 & $-165,4$ & $-0,1$ & $-21,9$ & & $-8,4$ & \\
\hline 4 & 8,6 & 4,6 & 16,6 & 3,6 & 1,9 & 0,5 & 5,4 & 45,7 & $-183,0$ & $-0,6$ & $-24,2$ & & $-7,2$ & \\
\hline 5 & 5,0 & 5,0 & 19,1 & 3,8 & 3,8 & 0,3 & 1,5 & 10,0 & $-171,4$ & $\begin{array}{l}-1,3 \\
\end{array}$ & $-22,6$ & & $-9,7$ & \\
\hline 6 & 7,3 & 6,1 & 20,6 & 3,4 & 2,8 & 0,4 & 5,2 & 21,3 & $-165,7$ & 2,2 & $-21,2$ & & $-7,7$ & \\
\hline
\end{tabular}

Примечания: 1 - Значения изотопных отночений $\delta^{18} O$ и $\delta D$ представлены относительно шкал VSMOW2-SLAP2, $\delta^{13} C_{D I C}$ - относительно VPDB; 2 - Величины $\Delta \delta D, \Delta \delta^{18} O, \Delta \delta^{13} C_{D I C}$ отражают максимальные отклонения измеренных значений от усредненных $\delta D, \delta^{18} O$ и $\delta^{13} C_{D I C}$ (неоднородность образиа по изотопу).

Note: 1 - The values of the isotopic ratios $\delta^{18} O$ and $\delta D$ are presented relative to the scales VSMOW2-SLAP2, $\delta^{13} C_{D I C}-$ relative VPDB; 2 - Values $\Delta \delta D, \Delta \delta^{18} O, \Delta \delta^{13} C_{D I C}$ reflect the maximum deviations of the measured values from the averaged $\delta D$, $\delta^{18} O$ and $\delta^{13} C_{D I C}$ (sample heterogeneity by isotope).

\section{Заключение}

Исходя из вышесказанного можно сделать следующие выводы. Изучено два типа водопунктов: 1) реки; 2) временные водотоки, образующиеся в период таяния многолетнемерзлых пород. Воды относятся к ультрапресным с величиной общей минерализации, варьирующей от 63 до 100 мг/дм ${ }^{3}$, нейтральным и слабощелочным (pH 6,9-7,9) с показателем ХПК от 1,6 до $9,7 \mathrm{m \Gamma O} /$ дм $^{3}$. Содержания кремния составляют от 0,6 до 1,3 мг/дм ${ }^{3}$. Каждый водопункт характеризуется своим химическим типом, преобладающими ионами являются $\mathrm{HCO}_{3}\left(58 \mathrm{мг} /\right.$ дм $\left.^{3}\right)$ и $\mathrm{Ca}\left(19 \mathrm{мг} /\right.$ дм $\left.^{3}\right)$. Отличительной чертой временных водотоков является преобладание в этих водах сульфат-иона от 24 до 36 мг/дм³.

Рассчитанные геохимические коэффициенты показали, что временные водотоки № 1, 2 отличаются высоким отношением $\mathrm{SO}_{4} / \mathrm{Cl}$ (46-83). Предположительно это связано с дренированием массива пород с наличием сульфидной минерализации. О преобладании во вмещающих породах кальциевых минералов говорит отношение $\mathrm{Ca} / \mathrm{Si}$, которое возрастает от 14 до 20 по гидрогеохимическому профилю от водопункта № 1 к № 6. По другим геохимическим коэффициентам $(\mathrm{Ca} / \mathrm{Na}, \mathrm{Ca} / \mathrm{Mg}, \mathrm{Mg} / \mathrm{Si}, \mathrm{Na} / \mathrm{Si}, \mathrm{Si} / \mathrm{Na}, \mathrm{rNa} / \mathrm{rCl})$ не удалось выявить значимых различий.

$\mathrm{C}$ ростом общей минерализации возрастают концентрации таких элементов, как: $\mathrm{B}, \mathrm{Si}, \mathrm{Sc}, \mathrm{V}, \mathrm{Cr}, \mathrm{Mn}$, $\mathrm{Co}, \mathrm{Cu}, \mathrm{Zn}, \mathrm{Ga}$, As, Se, Br, Rb, Y, Sn, Ba, Pb, Th и U, но снижаются концентрации $\mathrm{Ti}, \mathrm{Al}, \mathrm{Fe}, \mathrm{Ni}, \mathrm{Ge}, \mathrm{Sr}, \mathrm{Sb}, \mathrm{I}$. Можно выделить несколько объектов, в которых установлены максимальные концентрации ряда элементов: в водопаде № 2 (№ 4) - $\mathrm{Br} 0,013 \mathrm{мг} /$ дм $^{3}$, Мо 0,0003 мг/дм ${ }^{3}$, в водопаде (косой распадок) (№ 5) $\mathrm{Ni}$ 0,003 мг/дм ${ }^{3}$, I 0,071 мг/дм³ и в водах реки Атыркан (№ 6) - Zn 0,003 мг/дм³ и Mn 0,01 мг/дм³. Также выделяются объекты с минимальными концентрациями:

\section{СПИСОК ЛИТЕРАТУРЫ}

1. Фотиев С.М. Подземные воды криогенной области России (классификация) // Криосфера Земли. - 2013. - Т. XVII. № 2. - C. 41-59.

2. Государственная геологическая карта Российской Федерации Масштаб 1:1000000 (третье поколение). Серия ВерхояноКолымская. Лист R-52 - Тикси. Объяснительная записка / в реке Непелях (№ 2) - $\mathrm{Pb}$ до 9.10-6, Тh до $2 \cdot 10^{-6}$ мг/дм ${ }^{3}$, в водопаде № 2 (№ 4) - Mn до 0,0003 мг/дм ${ }^{3}$, Ті до 0,0002 мг/дм ${ }^{3}$ и V до $9 \cdot 10^{-6}$ мг/дм

Рассчитанные коэффициенты концентрации и водной миграции выявили особенности накопления элементов в водах. Первый показал, что в изучаемых водах не наблюдается значимых величин их концентрирования. По второму очень сильной интенсивностью миграции обладают I, Se, Br; сильной $\mathrm{Sr}, \mathrm{B}, \mathrm{Sb}$; средней As, P, Ni, Cu, Li, Ba, Zn, U, Sn, Мо и слабой (инертной) Sc, Y, Be, Mn, Pb, Si, Ge, Cr, Rb, Co, V, Fe, $\mathrm{Ga}$, Th, Al, Zr, Ti. Некоторые элементы из установленных А.И. Перельманом рядов миграции переходят из своих привычных групп, что можно связать с большим антропогенным влиянием на поверхностные воды изучаемого региона и их повышенными содержаниями в дренируемых породах относительно кларка. Детальные литолого-минералогические исследования горных пород ведутся в настоящее время.

Использование комплекса $\left[\delta^{13} \mathrm{C}_{\mathrm{DIC}}+\delta^{18} \mathrm{O}+\delta \mathrm{D}\right]$ позволяет однозначно отнести исследованные воды к метеорным. Наблюдается смещение акцента питания вод от зимнего к летнему для рек, в то время как для водопадов в большей степени проявляются зимние (снеговые) источники. В ходе «маршрута» следования вод наблюдается их обогащение изотопом ${ }^{13} \mathrm{C}_{\mathrm{DIC}}$. Наиболее вероятными источниками утяжеления изотопного состава представляются углекислота, образованная в ходе вегетации растений типа $\mathrm{C}_{4}$, a также вероятный обмен изотопами углерода с карбонатными породами.

Исследования проводились при финансовой поддержке проектов ФНИ № 0331-2019-0004, 0331-2019-0021, 0331-2019-0025 и Российского фонда фундаментальных исследований в рамках научных проектов № 18-05-70074 «Ресурсы Арктики» и № 19-05-00130.

М.В. Герцева, Т.П. Борисова, Е.Д. Чибисова, Е.Н. Емельянова, В.Г. Черенков, Л.М. Игнатьева, И.А. Котов, Е.Б. Истошина, И.А. Федосеев. - СПб.: Картографическая фабрика ВСЕГЕИ, 2016. $-312 \mathrm{c}$

3. Габышев В.А., Габышева О.И. К изучению фитопланктона и физико-химических параметров вод р. Оленек // Вестник СВНЦ ДВО РАН. - 2010. - № 3. - С. 51-55. 
4. Перельман А.И. Геохимия ландшафта. Изд. 2-е. - М.: Высшая школа, 1975. - 342 c.

5. Григорьев Н.А. Распределение химических элементов в верхней части континентальной коры // Уральский геологический журнал. - 2010. - № 3 (75). - С. 85-90.

6. Stable water isotope modeling reveals spatio-temporal variability of glacier meltwater contributions to Ganges River headwaters / S. Boral, I.S. Sen, D. Ghosal, B. Peucker-Ehrenbrink, J.D. Hemingway // Journal of Hydrology. - 2019. -V. 577. 123983.

7. Stream water age distributions controlled by storage dynamics and nonlinear hydrologic connectivity: modeling with high-resolution isotope data / C. Soulsby, C. Birkel, J. Geris, J. Dick, C. Tunaley, D. Tetzlaff // Water Resour. Res. - 2015. - V. 51. - P. 7759-7776.

8. Hydrochemical and isotopic characterization of groundwater in the Ghis-Nekor plain (northern Morocco) / D. Chafouq, A.El. Mandour, M. Elgettafi, M. Himi, I. Chouikri, A. Casas // Journal of African Earth Sciences. - 2018. - V. 139. - P. 1-13.

9. Spatial distribution and controlling factors of surface water stable isotope values $(\delta 18 \mathrm{O}$ and $\delta 2 \mathrm{H})$ across Kazakhstan, Central Asia / H. Wu, J. Wu, F. Song, J. Abuduwaili, A.S. Saparov, X. Chen, B. Shen // Science of the Total Environment. - 2019. - V. 678. P. 53-61.

10. Using $\mathrm{H}, \mathrm{O}, \mathrm{Rn}$ isotopes and hydrometric parameters to assess the surface water-groundwater interaction in coastal wetlands associated to the marginal forest of the Río de la Plata L. Santucci, R. Sanci, E. Carol, E. Villalba, H. Panarello // Continental Shelf Research. - 2019. - V. 186. - P. 104-110.

11. $\mathrm{O}, \mathrm{H}, \mathrm{C}$ isotope geochemistry of carbonated mineral springs in central Victoria, Australia: sources of gas and water-rock interaction during dying basaltic volcanism / I Cartwright. T. Weaver, S. Tweed, D. Ahearne, M. Cooper, C. Czapnik, J. Tranter // Journal of Geochemical Exploration. - 2000. V. 257-26. - P. 69-70.

12. Aydin H., Karakus H., Mutlu H. Hydrogeochemistry of geothermal waters in eastern Turkey: Geochemical and isotopic constraints on water-rock interaction // Journal of Volcanology and Geothermal Research. - 2020. - V. 390. - 106708. URL: https://doi.org/10.1016/j.jvolgeores.2019.106708 (дата обращения: 01.06.2020).

13. Environmental controls on the carbon and water ( $\mathrm{H}$ and $\mathrm{O}$ ) isotopes in peatland Sphagnum mosses / Z. Xia, Y. Zheng, J.M. Stelling, J. Loisel, Y. Huang, Z. Yu // Geochimica et Cosmochimica Acta. - 2020. - V. 277. - P. 265-284.

14. Craig H. Isotopic variations in meteoric waters // Science. 1961. - V. 133. - P. 1702-1703.

15. Newman C.P. Poulson S.R., Hanna B. Regional isotopic investigation of evaporation and water-rock interaction in mine pit lakes in Nevada, USA // Journal of Geochemical Exploration. 2020. - V. 210. - 106445.

16. Genesis of formation water in the northern sedimentary basin of South China Sea: clues from hydrochemistry and stable isotopes (D, 180, 37Cl and 81Br) / H. Yu, T. Ma, Y. Du, L. Chen // Journal of Geochemical Exploration. - 2019. - V. 196. - P. 57-65.

17. Wenninger J., Beza D.T., Uhlenbrook S. Experimental investigations of water fluxes within the soil-vegetationatmosphere system: stable isotope mass-balance approach to partition evaporation and transpiration // Physics and Chemistry of the Earth. - 2010. - V. 35. - P. 565-570.

18. Sources and sinks of dissolved inorganic carbon in an urban tropical coastalbay revealed by $\delta 13 \mathrm{C}$-DIC signals / L.C. Cotovicz Jr., B.A. Knoppers, L. Deirmendjian, G. Abril // Estuarine, Coastal and Shelf Science. - 2019. - V. 220. - P. 185-195.

19. Das A., Krishnaswami S., Bhattacharya S.K. Carbon isotope ratio of dissolved inorganic carbon (DIC) in rivers draining the Deccan Traps, India: sources of DIC and their magnitudes // Earth and Planetary Science Letters. - 2005. - V. 236. - Iss. 1-2. - P. 419-429.

20. Deirmendjian L., Abril G. Carbon dioxide degassing at the groundwater-stream-atmosphere interface: isotopic equilibration and hydrological mass balance in a sandy watershed // Journal of Hydrology. - 2018. - V. 558. - P. 129-143.

21. Zhang J., Quay P.D., Wilbur D.O.Carbon isotope fractionation during gas-water exchange and dissolution of $\mathrm{CO} 2 / /$ Geochimica et Cosmochimica Acta. - 1995. - V. 59. - Iss. 1. - P. 107-114.

22. Global Monitoring Laboratory. URL: http://www.cmdl.noaa.gov/ ccgg/iadv/ (дата обращения: 01.06.2020).

23. Liu Z., Dreybrodt W., Wang H. A new direction in effective accounting for the atmospheric $\mathrm{CO} 2$ budget: considering the combined action of carbonate dissolution, the global water cycle and photosynthetic uptake of DIC by aquatic organisms // EarthScience Reviews. - 2010. - V. 99. - № 3-4. - P. 162-172.

24. Carbon isotope signature of dissolved inorganic carbon (DIC) in precipitation and atmospheric CO2 / M. Górka, P.E. Sauer, D. Lewicka-Szczebak, M.-O. Jędrysek // Environmental PollutionVolume. - 2011. - V. 159. - № 1. - P. 294-301.

25. Keith M.L., Weber J.N. Isotopic composition and environmental classification of selected limestone and fossils // Geochim. Cosmochim. Acta. - 1964. - V. 28. - P. 1787-1816.

26. Quantifying carbon isotope disequilibrium during in-cave evolution of drip water along discreet flow paths / P.J. Mickler, P. Carlson, J.L. Banner, D.O. Breecker, L. Stern, A. Guilfoyle // Geochimica et Cosmochimica Acta. - 2019. - V. 244. - P. 182-196.

Поступила: 08.06.2020 г.

\section{Информация об авторах}

Новиков Д.А., кандидат геолого-минералогических наук, заведующий лабораторией гидрогеологии осадочных бассейнов Сибири Института нефтегазовой геологии и геофизики им. А.А. Трофимука СО РАН; доцент кафедры геологии месторождений нефти и газа и кафедры общей и региональной геологии Новосибирского национального исследовательского государственного университета.

Максимова $\boldsymbol{A}$.A., студент Новосибирского национального исследовательского университета.

Пыряев $\boldsymbol{A . H . , ~ к а н д и д а т ~ х и м и ч е с к и х ~ н а у к , ~ м л а д ш и и ̆ ~ н а у ч н ы и ̆ ~ с о т р у д н и к ~ л а б о р а т о р и и ~ и з о т о п н о - а н а л и т и ч е с к о и ̆ ~}$ геохимии Института геологии и минералогии им. В.С. Соболева СО РАН; ассистент кафедры химической и биологической физики Новосибирского национального исследовательского государственного университета.

Ян П.А., кандидат геолого-минералогических наук, заведующий лабораторией седиментологии Института нефтегазовой геологии и геофизики им. А.А. Трофимука СО РАН; доцент кафедры общей и региональной геологии Новосибирского национального исследовательского государственного университета. 
UDC 556:550.845 (292.511/.516)

\title{
FIRST ISOTOPE-HYDROGEOCHEMICAL DATA ON THE NATURAL WATERS OF THE SOUTH-EAST SLOPE OF THE CHEKANOVSKY RIDGE (ARCTIC AREAS OF THE SIBERIAN PLATFORM)
}

Dmitry A. Novikov1,2, NovikovDA@ipgg.sbras.ru

\section{Anastasia A. Maksimova²,} rock.nastaya64@gmail.com

\author{
Aleksandr N. Pyrayev3,2, \\ pyrayev@igm.nsc.ru \\ Petr A. Yan1,2, \\ YanPA@ipgg.sbras.ru \\ 1 Trofimuk Institute of Petroleum Geology and Geophysics SB RAS, \\ 3/6, Koptyug avenue, Novosibirsk, 630090, Russia. \\ 2 Novosibirsk State University, \\ 1, Pirogov street, Novosibirsk, 630090, Russia. \\ 3 Institute of Geology and Mineralogy SB RAS, \\ 3, Koptyug avenue, Novosibirsk, 630090, Russia.
}

The relevance of the study is caused by the obtaining of the previously unexplored isotope-hydrogeochemical data on the natural waters of the south-east slope of the Chekanovsky ridge (Arctic regions of the Siberian Platform). The study area is difficult due to the access continuous distribution of permafrost.

The aim of the research is to identify the geochemical features of the natural waters of the south-east slope of the Chekanovsky ridge. Methods. Field sampling was carried out in accordance with generally accepted methods. Chemical analytical studies were performed by titrimetry, ion chromatography and inductively coupled plasma mass spectrometry. The analysis of the isotope ratios $\left(\delta D\right.$, $\delta^{18} O$, and $\delta^{13} C_{D I C}$ ) was carried out on an Isotope Ratio Mass Spectrometer Finnigan ${ }^{T M} M A T 253$ equipped with H/Device (for analyzing $\delta D$ ratios) and GasBench II (for analyzing $\delta^{18} \mathrm{O}$ and $\delta^{13} \mathrm{C}_{\mathrm{DIC}}$ ratios) sample preparation attachments. In the study of hydrogeochemical data, we used geochemical coefficients ( $\mathrm{Ca} / \mathrm{Na}, \mathrm{Ca} / \mathrm{Mg}, \mathrm{Ca} / \mathrm{Si}, \mathrm{Mg} / \mathrm{Si}, \mathrm{Na} / \mathrm{Si}, \mathrm{Si} / \mathrm{Na}, \mathrm{rNa} / \mathrm{rCl}$ and $\left.\mathrm{SO}_{4} / \mathrm{Cl}\right)$, coefficients of concentration and water migration according to A.I. Perelman.

Results. The paper presents the first results of isotope-geochemical studies of the natural waters of the south-east slope of the Chekanovsky ridge, located in the downstream of the Lena river, in the Arctic regions of the Siberian Platform. The rivers and temporary streams formed during the period of thawing of permafrost have been studied. It was established that the waters are ultra-fresh with a total salinity of 63 to $100 \mathrm{mg} / \mathrm{dm}^{3}$, neutral and slightly alkaline in terms of $\mathrm{pH}(6,9-7,9)$, characterized by chemical oxygen demand (COD) from 1,6 to $9,7 \mathrm{mgO} / \mathrm{dm}^{3}$. River waters have a predominantly bicarbonate calcium composition. Temporary streams are characterized by the predominance of sulfate ion, as well as low COD values - from 1,6 to 3,1 $\mathrm{mgO} / \mathrm{dm}^{3}$. The calculated coefficients of water migration were distributed as follows: very high intensity of migration of I, Se, Br; high Sr, B, Sb; average As, P, Ni, Cu, Li, Ba, Zn, U, Sn, Mo; low Sc, Y, Be, Mn, Pb, $\mathrm{Si}, \mathrm{Ge}, \mathrm{Cr}, \mathrm{Rb}, \mathrm{Co}, \mathrm{V}, \mathrm{Fe}, \mathrm{Ga}, \mathrm{Th}, \mathrm{Al}, \mathrm{Zr}$, Ti. The isotopic ratios of oxygen and hydrogen were studied in a wide range for $\delta^{18} \mathrm{O}-\mathrm{from}-24,2$ to $-19,5 \%$, and for $\delta D$ - from $-183,0$ to $-149,3 \%$. According to the isotopic composition the waters has a meteor origin. A shift in the water supply from winter to summer is observed for rivers, while winter (snow) sources are more pronounced for temporary streams. The $\delta^{13} C_{D I C}$ isotopic ratios range from $-9,7$ to $-7,2 \%$. In river waters, both positive (up to $-7,2 \%$ ) and negative (up to $-9,7 \%$ ) deviations of $\delta^{13} \mathrm{C}$ relative to samples taken from temporary streams (characterized by values from $-8,0$ to $-7 \%$ ), are observed. It supposed enrichment of water with carbon dioxide and heavy isotope ${ }^{13} \mathrm{C}$ firstly due to material and isotopic exchange with the carbonate rocks weathered by soil $\mathrm{CO}_{2}$ formed from plants of type $\mathrm{C}_{4}$.

\section{Key words:}

Natural waters, chemical composition, stable isotopes $\delta^{18} \mathrm{O}, \delta D, \delta^{13} \mathrm{C}_{D I C}$, permafrost rocks,

intensity of water migration of elements, south-east slope of the Chekanovsky ridge, Siberian platform, Arctic.

The research was financially supported by the FSR no. 0331-2019-0004, 0331-2019-0021, 0331-2019-0025 and the Russian Foundation for Basic Research as part of the scientific project no. 18-05-70074 «Arctic Resources» and no. 19-05-00130.

\section{REFERENCES}

1. Fotiev S.M. Underground waters of cryogenic area of Russia (classification). Earth's Cryosphere, 2013, vol. XVII, no. 2, pp. 41-59. In Rus.

2. Gertseva M.V., Borisova T.P., Chibisova E.D., Emelyanova E.N., Cherenkov V.G., Ignatyeva L.M., Kotov I.A., Istoshina E.B., Fe- doseev I .A. Gosudarstvennaya geologicheskaya karta Rossiyskoy Federatsii. Masshtab 1:1000000 (tretye pokoleniye). Seriya Verkhoyano-Kolymskaya. List $R-52$ - Tiksi. Obyasnitelnaya zapiska [State geological map of the Russian Federation. Scale 1:1000000 (third generation). Series Verkhoyano-Kolyma. Sheet R-52 - Tiksi. Explanatory note]. St-Petersburg, Cartographic Factory VSEGEI Publ., 2016. 312 p. 
3. Gabyshev V.A., Gabysheva O.I. K izucheniyu fitoplanktona i fiziko-khimicheskikh parametrov vod r. Olenek [To the study of phytoplankton and physicochemical parameters of the Olenek river waters]. Bulletin SVNTS FEB RAS, 2010, no. 3, pp. 51-55.

4. Perelman A.I. Geokhimiya landshafta [Landscape geochemistry] Moscow, Vysshaya shkola Publ., 1975. 342 p.

5. Grigoryev N.A. Raspredelenie khimicheskikh elementov v verkhney chasti kontinentalnoy kory [Distribution of chemical elements in the upper continental crust]. Uralskiy geologicheskiy zhurnal, 2010, no. 3 (75), pp. 85-90.

6. Boral S., Sen I.S., Ghosal D., Peucker-Ehrenbrink B., Hemingway J.D. Stable water isotope modeling reveals spatio-tempora variability of glacier meltwater contributions to Ganges River headwaters. Journal of Hydrology, 2019, vol. 577, 123983.

7. Soulsby C., Birkel C., Geris J., Dick J., Tunaley C., Tetzlaff D. Stream water age distributions controlled by storage dynamics and nonlinear hydrologic connectivity: modeling with high-resolution isotope data. Water Resources Research, 2015, vol. 51, pp. 7759-7776.

8. Chafouq D., Mandour A.El., Elgettafi M., Himi M., Chouikri I., Casas A. Hydrochemical and isotopic characterization of groundwater in the Ghis-Nekor plain (northern Morocco). Journal of African Earth Sciences, 2018, vol. 139, pp. 1-13.

9. Wu H., Wu J., Song F., Abuduwaili J., Saparov A.S., Chen X., Shen B. Spatial distribution and controlling factors of surface water stable isotope values $(\delta 18 \mathrm{O}$ and $\delta 2 \mathrm{H})$ across Kazakhstan, Central Asia. Science of the Total Environment, 2019, vol. 678, pp. 53-61.

10. Santucci L., Sanci R., Carol E., Villalba E., Panarello H. Using H, $\mathrm{O}, \mathrm{Rn}$ isotopes and hydrometric parameters to assess the surface water-groundwater interaction in coastal wetlands associated to the marginal forest of the Río de la Plata. Continental Shelf Research, 2019, vol. 186, pp. 104-110.

11. Cartwright I., Weaver T., Tweed S., Ahearne D., Cooper M. Czapnik C., Tranter J. O, H, C isotope geochemistry of carbonated mineral springs in central Victoria, Australia: sources of gas and water-rock interaction during dying basaltic volcanism. Journal of Geochemical Exploration, 2000, vol. 257-26, pp. 69-70.

12. Aydin H., Karakuş H., Mutlu H. Hydrogeochemistry of geothermal waters in eastern Turkey: Geochemical and isotopic constraints on water-rock interaction. Journal of Volcanology and Geothermal Research, 2020, vol. 390, 106708. Available at: https://doi.org/10.1016/j.jvolgeores.2019.106708 (accessed 1 June 2020).

13. Xia Z., Zheng Y., Stelling J.M., Loisel J., Huang Y., Yu Z. Environmental controls on the carbon and water $(\mathrm{H}$ and $\mathrm{O})$ isotopes in peatland Sphagnum mosses. Geochimica et Cosmochimica Acta, 2020, vol. 277, pp. 265-284

14. Craig H. Isotopic variations in meteoric waters. Science, 1961 , vol. 133 , pp. $1702-1703$.

\section{Information about the authors}

Dmitry A. Novikov, Cand. Sc., head of the laboratory, Trofimuk Institute of Petroleum Geology and Geophysics of Siberian Branch of Russian Academy of Sciences; associate professor, Novosibirsk State University.

Anastasia A. Maksimova, student, Novosibirsk State University.

Aleksandr N. Pyrayev, Cand. Sc., junior researcher, Institute of Geology and Mineralogy SB RAS; assistant, Novosibirsk State University.

Petr A. Yan, Cand. Sc., head of the laboratory, Trofimuk Institute of Petroleum Geology and Geophysics of Siberian Branch of Russian Academy of Sciences; associate professor, Novosibirsk State University.
15. Newman C.P., Poulson S.R., Hanna B. Regional isotopic investigation of evaporation and water-rock interaction in mine pit lakes in Nevada, USA. Journal of Geochemical Exploration, 2020, vol. 210, article 106445

16. Yu H., Ma T., Du Y., Chen L. Genesis of formation water in the northern sedimentary basin of South China Sea: Clues from hydrochemistry and stable isotopes (D, $180,37 \mathrm{Cl}$ and $81 \mathrm{Br}$ ). Journal of Geochemical Exploration, 2019, vol. 196, pp. 57-65.

17. Wenninger J., Beza D.T., Uhlenbrook S. Experimental investigations of water fluxes within the soil-vegetation-atmosphere system: Stable isotope mass-balance approach to partition evaporation and transpiration. Physics and Chemistry of the Earth, 2010, vol. 35, p. 565-570.

18. Cotovicz Jr. L.C., Knoppers B.A., Deirmendjian L., Abril G. Sources and sinks of dissolved inorganic carbon in an urban tropical coastalbay revealed by $\delta 13 \mathrm{C}$-DIC signals. Estuarine, Coastal and Shelf Science, 2019, vol. 220, pp. 185-195.

19. Das A., Krishnaswami S., Bhattacharya S.K. Carbon isotope ratio of dissolved inorganic carbon (DIC) in rivers draining the Deccan Traps, India: Sources of DIC and their magnitudes. Earth and Planetary Science Letters, 2005, vol. 236, Iss. 1-2, pp. 419-429

20. Deirmendjian L., Abril G. Carbon dioxide degassing at the groundwater-stream-atmosphere interface: isotopic equilibration and hydrological mass balance in a sandy watershed. Journal of Hydrology, 2018, vol. 558, pp. 129-143.

21. Zhang J., Quay P.D., Wilbur D.O. Carbon isotope fractionation during gas-water exchange and dissolution of $\mathrm{CO}_{2}$. Geochimica et Cosmochimica Acta, 1995, vol. 59, Iss. 1, pp. 107-114.

22. Global Monitoring Laboratory. Available at: http://www.cmdl. noaa.gov/ccgg/iadv/ (accessed 1 June 2020).

23. Liu Z., Dreybrodt W., Wang H. A new direction in effective accounting for the atmospheric $\mathrm{CO} 2$ budget: Considering the combined action of carbonate dissolution, the global water cycle and photosynthetic uptake of DIC by aquatic organisms. Earth-Science Reviews, 2010, vol. 99, Iss. 3-4, pp. 162-172.

24. Górka M., Sauer P.E., Lewicka-Szczebak D., Jędrysek M.-O. Carbon isotope signature of dissolved inorganic carbon (DIC) in precipitation and atmospheric $\mathrm{CO}_{2}$. Environmental Pollution Volume, 2011, vol. 159, Iss. 1, pp. 294-301.

25. Keith M.L., Weber J.N. Isotopic composition and environmental classification of selected limestone and fossils. Geochimica et Cosmochimica Acta, 1964, vol. 28, pp. 1787-1816.

26. Mickler P.J., Carlson P., Banner J.L., Breecker D.O., Stern L., Guilfoyle A. Quantifying carbon isotope disequilibrium during incave evolution of drip water along discreet flow paths. Geochimica et Cosmochimica Acta, 2019, vol. 244, pp. 182-196.

Received: 8 June 2020. 